\title{
An empirical investigation of construction and demolition waste generation rates in Shenzhen city, South China
}

\author{
Weisheng Lu${ }^{1}$, Hongping Yuan ${ }^{2,}{ }^{*}$, Jingru $\mathrm{Li}^{3}$, Jane J.L. Hao ${ }^{4}$, Xuming, $\mathrm{Mi}^{3}$ and \\ Zhikun Ding $^{3}$
}

1 Department of Real Estate and Construction, University of Hong Kong, Hong Kong.

2 Department of Building and Real Estate, The Hong Kong Polytechnic University, Hong Kong.

3 Faculty of Civil Engineering, Shenzhen University, Guangdong, 518060, China

4 Department of Architecture, Ryerson University, Canada.

* author for corresponding

Department of Building and Real Estate, The Hong Kong Polytechnic University, Hung Hom, Kowloon, Hong Kong.

Tel: +852 27664306 Fax: +852 27645131 Email: hpyuan2005@gmail.com (H.P. Yuan) 


\section{Abstract}

The construction and demolition waste generation rates (C\&D WGRs) is an important factor in decision-making and management of material waste in any construction site. The present study investigated WGRs by conducting on-site waste sorting and weighing in four ongoing construction projects in Shenzhen city of South China. The results revealed that WGRs ranged from 3.275 to $8.791 \mathrm{~kg} / \mathrm{m}^{2}$ and miscellaneous waste, timber for formwork and falsework, and concrete were the three largest components among the generated waste. Based on the WGRs derived from the research, the paper also discussed the main causes of waste in the construction industry and attempted to connect waste generation with specific construction practices. It was recommended that measures mainly including performing waste sorting at source, employing skilful workers, uploading and storing materials properly, promoting waste management capacity, replacing current timber formwork with metal formwork and launching an incentive reward program to encourage waste reduction could be potential solutions to reducing current WGRs in Shenzhen. Although these results were derived from a relatively small sample and so cannot justifiably be generalized, they do however add to the body of knowledge that is currently available for understanding the status of the art of C\&D waste management in China.

\section{Keywords}

Construction and demolition waste, waste management, waste generation rate, benchmarking, China 


\section{Introduction}

The waste generation rate (WGR) is one of the most useful variables that lie at the core of many efforts for understanding waste management in the construction sector. First, it can provide quantitative information for benchmarking different construction and demolition (C\&D) waste management (WM) practices. Normally, it is assumed that different C\&D WM practices, such as work procedures and construction technologies, will lead to different levels of $C \& D$ waste generation. By comparing the WGRs in different projects and regions, it is possible to identify a set of good practices for managing C\&D waste. Second, it helps raise people's awareness of WM in the construction industry. By using the WGR, it is possible to calculate the total quantity of $C \& D$ waste and thus inform people of the negative impacts that construction activities have on the environment. Third, it can assist contractors with developing effective C\&D WM strategies. For example, researchers (e.g. McDonald and Smithers, 1998; Poon et al., 2001a) have identified the importance of a waste management plan as part of a C\&D WM strategy. One of the critical steps to make a sound waste management plan is to estimate quantities of $C \& D$ waste based on WGRs.

Owing to its significance, the investigation of WGR has long been attractive to researchers as well as construction practitioners. Skoyles (1976) examined WGRs for 37 materials in the UK through direct on-site observations and by comparing contractors’ records. Bossink and Brouwers (1996) investigated material waste rates 
in the Netherlands and compared them with those in other countries to identify the consequence of using different construction techniques, work procedures, and common practices. Mcdonald and Smithers (1998) conducted a study on WGR in Australia by comparing C\&D WM practices on two projects. Formoso et al. (2002) calculated WGRs for 8 materials in Brazil based on contractors' material supply records and direct observation. A series of research on WGRs for various construction materials in Hong Kong, were reported by Poon et al. (2001a, 2004a, 2004b, 2004c). Tam et al. (2007) assessed the WGRs affected by sub-contracting relationships and project types with their correlations. All these studies provide important references for comparing WGRs in different economics. As a whole they also provide significant insights into the management of waste in the construction sector.

Nonetheless, it seems that scant research has been conducted to investigate WGRs in China. Researchers in the country still cite an extant approximate WGR of 500-600t per $10,000 \mathrm{~m}^{2}$ provided by Lu (1999) ten years ago, who, without describing the study's methodology based the WGR on a rule-of-thumb. According to Lu and Yuan (2010), expanding urbanization and enormous construction activities associated with rapid economic development has generated a large amount of C\&D waste in China, which in turn has caused a severe degradation of its environment. There is a pressing need to understand the generation of C\&D waste in this fast developing construction sector. Moreover, today’s C\&D waste together with its environmental impact in a particular region is no longer merely a local issue. It is therefore important to 
investigate and compare WGRs in different countries so that knowledge developed elsewhere can be shared in China rather than reinventing the wheel.

The primary aim of this research was to conduct an empirical investigation of C\&D WGRs in Shenzhen city of South China and propose recommendations for improving the performance of C\&D WM. The research unfolded in four stages, the first of which was a critical literature review in order to provide an understanding of various concepts including C\&D WM measures for WGRs, and methodologies for investigating WGRs. The second stage was an investigation of C\&D WGRs by conducting waste sorting and weighing at four sites in Shenzhen, whilst the third and fourth stages analyzed the data and provided findings for discussions respectively.

\section{Critical literature review}

\subsection{Construction and demolition waste management}

When considering $C \& D$ waste it is important to define what is meant by the term. Generally, it is defined as the solid waste that arises from construction, renovation and demolition activities. Roche and Hegarty (2006) added that C\&D waste also includes surplus and damaged products and materials arising in the course of construction work or used temporarily during the course of on-site activities. The European Waste Catalogue (EWC) classifies C\&D waste into the following eight categories: (1) concrete, bricks, tiles and ceramics; (2) wood, glass and plastic; (3) bituminous 
mixtures, coal tar and tarred products; (4) metals (including their alloys), (5) soil (including excavated soil from contaminated sites), stones and dredging spoil; (6) insulation materials and asbestos-containing construction materials; (7) gypsum-based construction material; (8) other construction and demolition waste. In Hong Kong, the composition of C\&D waste is divided into the two major categories of inert materials and non-inert waste (EPD, 1998). The inert materials comprise soft inert materials such as soil, earth, silt, slurry as well as hard inert materials such as rocks and broken concrete, whilst the non-inert materials include metals, timber, plastics and packaging waste (Poon, 2007; Lampris et al., 2009).

While acknowledging its significant contribution to the built environment, construction has caused negative impacts on the natural environment. Construction by nature is not environmentally friendly; it generates tremendous $C \& D$ waste resulting from various construction activities. Statistics show the significant impact that construction activities have on the environment in different countries (EPA, 2002; DETR, 2000; Reddrop and Ryan, 1997; Wang et al., 2004). With the increasing embracement of sustainable development as a new value (WCED, 1987), the construction industry has started to realize its adverse impact on the environment. Nowadays, C\&D WM is an emerging discipline that has attracted widespread interest around the world. Lu and Yuan (2010) summarized some key trends in the C\&D WM research and practices. First, previous C\&D WM can best be understood by putting it into a "C\&D WM Spectrum” ranging from "hard” construction technology to "soft” 
WM approaches, and by looking at it as a multidiscipline effort requiring inputs from different professionals. Second, C\&D WM is guided by a "3Rs" principle, which outlines the different priorities of strategies that are available for managing $C \& D$ waste. Third, thinking of C\&D WM has been extended to the whole lifecycle of a project and involves several stakeholders.

In addition to the above three key trends, there is a prevailing culture of measuring performance in C\&D WM. According to OCIO (2007), performance measurement is the process whereby an organization establishes the parameters within which programs, investments, and acquisitions are expected to reach the desired results. The cliché 'you cannot improve what you cannot measure' offers a rationale for the research conducted to measure C\&D WM performance. It is vital that $C \& D W M$ is closely monitored, and its performance is presented unambiguously for developing good C\&D WM practices. Unlike C\&D waste, which is often used as an integral term in existing literature, this research tends to focus on the waste generated at the construction stage. In measuring C\&D WM performance, WGR has become the prevailing instrument.

\subsection{Waste generation rates (WGRs)}

Table 1 is a summary of previous studies that investigated WGRs. It is not an exhaustive list. 
Table 1 shows that generally there are two approaches for measuring waste generation: classifying waste into different categories or treating them as a whole. Since Skoyles (1976) investigated waste by differentiating 37 materials such as steel, cement, concrete, mortar, timber, and so on, many later studies (e.g. Bossink and Brouwers, 1996; Forsthe and Marsden, 1999; Formoso et al., 2002, Treloar et al., 2002; Tam et al., 2007) used a similar approach. However, other studies (e.g. Poon et al., 2004; Lin, 2006) derived a general WGR by using the volume $\left(\mathrm{m}^{3}\right)$ or quantity (tons) of waste generated per $\mathrm{m}^{2}$ of gross floor area (GFA) without differentiating between materials. Whichever way they are derived, WGRs serve two purposes: when classifying waste into different categories, they make it possible to investigate a specific waste according to its properties and causes (e.g. building technologies, material handling processes, waste treatment); and when treating waste as a whole, they help with understanding the total amount of waste generated from a project or multiple projects.

It can be seen from Table 1 that different practices measure waste either by weight $(\mathrm{kg}$ or ton) or by volume $\left(\mathrm{m}^{3}\right)$. The WGRs are then calculated by dividing the waste by either the amount purchased, the amount required by the design, or per $\mathrm{m}^{2}$ of GFA. Therefore, largely in accordance with the waste measures summarized by Formoso et al. (2002), the four typical measurements for WGRs are: (1) percentage of material 
purchased, (2) percentage of material required by the design, (3) $\mathrm{kg} / \mathrm{m}^{2}$ of GFA, and (4) $\mathrm{m}^{3} / \mathrm{m}^{2}$ of GFA. The measures should be appropriate for the properties of each material. For instance, Skoyles (1976) and Tam et al. (2007) used a unit of $\mathrm{m}^{3}$ for concrete, ton for reinforcement, $\mathrm{m}^{2}$ for formwork, $\mathrm{m}^{2}$ for brick/block, and $\mathrm{m}^{2}$ for tile. The measures should also be appropriate for different purposes and no one measure is particularly better than another. For example, by multiplying the rates in $\mathrm{kg} / \mathrm{m}^{2}$ of GFA or $\mathrm{m}^{3} / \mathrm{m}^{2}$ of GFA it is possible to calculate the total amount of waste generated, and by analyzing the rate in terms of the percentage of material purchased, it is possible to review the effectiveness of the purchasing department, logistics management, and materials storage.

Comparisons have been made of WGRs in different countries. For instance, McDonald and Smithers (1996) compared WGRs at a site in Australia with WGRs found on sites in Hong Kong, and Bossink and Brouwers (1996) compared WGRs in the Netherlands with those found in other countries. The latter study concluded that the big difference in WGRs may be as a consequence of different construction techniques, work procedures and common practices. Although it is arguable whether WM knowledge developed in one country can simply be applied to another country, comparisons between countries can help with benchmarking and identifying good WM practices. 
Previous WGR-related studies adopted different research methodologies: Skoyles (1976) investigated WGRs through direct observation and by comparing contractors' records; McGregor et al. (1993) utilized a questionnaire and telephone survey; Bossink and Brouwers (1996) derived data by sorting and weighing waste materials on site; Treloar et al. (2003) and Tam et al. (2007) collected data through consultation with construction company employees; and Poon et al. (2001a, 2004) conducted research through direct observation, tape measurement, and truck load records. It can be seen that research of this kind normally adopts either 'hard' methods of measuring waste, such as on-site sorting and weighing and truck load records, or "soft" methods, such as questionnaire surveys and interviews.

In summary, WGRs have been investigated in different countries. However, no similar research has been conducted in China where there is a pressing need to understand the generation of $C \& D$ waste. The aim of this research was therefore to investigate WGRs in Chinese construction sector. When investigating WGRs, as aforementioned, there are normally two approaches: (1) classifying wastes into different categories or (2) treating them as a whole. Four measures of WGRs are typically adopted: (a) percentage of material purchased, (b) percentage of material required by the design, (c) $\mathrm{kg} / \mathrm{m}^{2}$ of GFA, or (d) $\mathrm{m}^{3} / \mathrm{m}^{2}$ of GFA. There are two commonly adopted methodologies for investigating WGRs: (i) using 'hard' measures such as on-site sorting and weighing and/or truck load records, and (ii) using 'soft' measures such as questionnaire and/or interviews with construction employees. After considering their 
relative strengths and weaknesses, this research adopted a methodology that conducted on-site sorting, weighing and classifying C\&D waste into different categories. The $\mathrm{kg} / \mathrm{m}^{2}$ of GFA was adopted as the main measure for construction waste since it facilitates the identification of waste generated by a single process or sub-trade. Also, by multiplying the $\mathrm{kg} / \mathrm{m}^{2}$ by the GFA, it is possible to calculate the total quantity of waste generated by the entire structure.

\section{Research methodology}

The research was conducted between 20 January 2009 and 30 March 2009 on four on-going construction projects in Shenzhen, a coastal city in South China adjacent to Hong Kong. Table 2 is a brief summary of the profiles of the four projects namely Project A, Project B, Project C and Project D, under study. All of the projects are high-rise buildings with reinforced concrete framework structures. They were at a superstructure construction stage when the empirical investigations of C\&D WGRs were carried out. The research team performed a total of five measuring exercises: one each on Projects A, Project B, and Project D, and two on Project C's different floors for different trades. Therefore they were further coded as Project C-1 and Project C-2.

Insert Table 2 Here

As mentioned, the exercises were performed in line with different trades as this helps 
analyze the reasons and trades that lead to different WGRs. In this research, four typical trades concreting, formwork, masonry, and plastering relating to reinforced concrete framework structure construction were investigated. When a trade had finished, the site manager cordoned off an area of the construction site to facilitate the on-site measuring exercises. The area (usually a room plus a section of common walkway) was selected as being representative of a typical floor so that the WGRs derived from that area could be applied to the whole floor; the framework nature of the structures was a great help in this respect. GFA of the area was calculated from the floor drawings provided by the site manager and recorded as $A$ in an inventory form here for future use.

Before the waste in the selected area was weighed, physical sorting of the waste was carried out. It is observed that different C\&D wastes such as concrete, timber (from formwork and falsework), metal, brick and block, tiles, mortar, and PVC pipes, more or less, were generated in line with different trades. For the on-site waste measuring exercises, the research team was equipped with tools including (1) buckets with the net weight and volume already known, (2) a weighing scale, (3) shovels and wheelbarrows. Different types of C\&D wastes were weighted bucket by bucket and recorded in inventory forms. The research team was protected with health and safety measures such as gloves and goggles, throughout the exercises.

Data from the inventory forms was added together to get the quantities of construction 
material wastes in the selected area. By using the Formula (1) below, the WGRs of different waste materials were calculated and illustrated in Figure 1.

$$
\text { WGR }=\frac{\sum_{i=1}^{n} m_{i}}{A} \quad \text { Formula (1) }
$$

Where, $\mathrm{m}_{\mathrm{i}} \longrightarrow$ the quantity of one waste material for one bucket

$\mathrm{n}$ — the numbers of bucket

$A \_$the area selected for on-site sorting and weighing

Insert Figure 1 Here

\section{Findings and discussions}

This section analyzes and discusses the major findings revealed by the study. First, WGRs amongst the four projects are compared, followed by the main causes of the waste identified. Finally the present WGR is compared with the material loss rate (MLR) that is widely used in the Chinese Norms system.

\subsection{Comparison of the WGRs amongst the projects investigated}

Figure 1 clearly shows the amounts of different C\&D wastes and the corresponding WGRs in the projects investigated. In project $\mathrm{A}$, concrete and timber are the major wastes, with a WGR being $2.387 \mathrm{~kg} / \mathrm{m}^{2}$ and $1.678 \mathrm{~kg} / \mathrm{m}^{2}$ respectively. The least WGR is for metal $\left(0.073 \mathrm{~kg} / \mathrm{m}^{2}\right)$. This implies that contractors in this project should devote 
their waste reduction efforts to concrete and timer (formwork and falsework). Project B generates a much bigger proportion of miscellaneous particles of concrete, brick and mortar (WGR: $3.34 \mathrm{~kg} / \mathrm{m}^{2}$ ), compared with other wastes generated in the same project. This indicates that most wasted materials are mixed at sources that are difficult to be sorted into different categories. Similar situation is observed in project C (see Figures 1.c and 1.d), in which miscellaneous of mortar and concrete and miscellaneous of brick and mortar bear the largest WGRs $\left(1.587 \mathrm{~kg} / \mathrm{m}^{2}\right.$ and $1.14 \mathrm{~kg} / \mathrm{m}^{2}$ respectively). Finally, a large value of WGR of timber (formwork and falsework) $\left(1.905 \mathrm{~kg} / \mathrm{m}^{2}\right)$ is identified in project D. It is also worth noting that WGR of miscellaneous of various wastes $\left(0.786 \mathrm{~kg} / \mathrm{m}^{2}\right)$ in this project is comparable with that of Projects B, and C.

The WGRs of individual materials in the four projects that were investigated (see the last row of Table 3) are far smaller than the approximate WGR of 500-600t per $10,000 \mathrm{~m}^{2}$ suggested by Lu (1999). The temptation is to say that C\&D WM in China has been significantly improved over the past decade but this conclusion cannot be drawn as Lu’s (1999) research has not elaborated any substantiated methodology. The present research was conducted using a robust methodology involving on-site sorting and weighing, and the WGRs were investigated individually according to different major construction materials. It is therefore to claim that the WGRs in this research are arguably more reliable and certainly more informative.

Insert Table 3 Here 
A large variation in WGRs for the same material at different projects was noticed from Column 2 of Table 3. The explanation was that a random and unusual construction practice could lead to a significant waste of materials. For example, the high WGR of concrete in Project A was due to $326.1 \mathrm{~kg}$ of premixed concrete having been over-ordered and ending up as waste left on the site. If that amount is omitted from the calculations, the WGRs of concrete in the investigated projects would have been in the range $0.357-1.571 \mathrm{~kg} / \mathrm{m}^{2}$ instead of $0.357-2.387 \mathrm{~kg} / \mathrm{m}^{2}$. A cross project reference led to a similar situation; the WGR of concrete at Project A was nearly five times higher than that at Project B; a similar large variation was observed in WGRs for bricks and blocks, and for miscellaneous waste. The large variation is probably attributed to different approaches for C\&D WM, different levels of WM awareness, and different construction technologies, all of which vary from one contractor to another.

Furthermore, to facilitate comparison of WGRs of different materials, a mid-value of each WGR is calculated and shown in Column 3 of Table 3. It shows obviously that miscellaneous waste $\left(1.994 \mathrm{~kg} / \mathrm{m}^{2}\right)$, timer (formwork and falsework) $\left(1.796 \mathrm{~kg} / \mathrm{m}^{2}\right)$ and concrete $\left(1.372 \mathrm{~kg} / \mathrm{m}^{2}\right)$ account for the three biggest proportions in C\&D waste generation among the projects investigated. PVC pipes (WGR: $0.035 \mathrm{~kg} / \mathrm{m}^{2}$ ) and metal (WGR: $0.044 \mathrm{~kg} / \mathrm{m}^{2}$ ) are the least waste generation streams. 
It needs to be pointed out that the WGR ranges shown in Table 3 above should not be recognized as WGRs that can be generalized to other projects, particularly as they were derived from a relatively small sample. Given that 4,371,400 $\mathrm{m}^{2}$ of Gross Floor Area (GFA) was completed in Shenzhen in 2007 alone (NBS, 2008), any estimation based on the WGRs found in this research that investigated only five construction sites should be treated with caution. A larger sample was used by Formoso et al. (2002) who examined the distribution of cement waste on 41 sites, and also used the median value and the co-efficient of dispersion, instead of only the mean value and the co-efficient of variability, to represent WGRs. Therefore, in order to arrive at a reliable WGR or a WGR range for generalization purposes, it is proposed that a WGR that steadily converges to a certain number or a range with the increase of investigated site samples could be adopted for estimating waste in future projects.

The above analysis provides food for thought regarding the methods adopted for investigating WGRs. First, on-site sorting and weighing ensures more credible data for investigating WGRs, while a larger sample of sites helps with an understanding of WGR variations and increases confidence that they are reliable. Second, because it is simply not possible to investigate the GFA of all sites in order to derive WGRs for different materials, designating a representative area as adopted in this study may be an acceptable compromise. Third, when it is difficult to find such a representative area, other methods for investigating the quantity of waste generated from a floor can be used, such as sorting and weighing all the waste on that floor before it is discharged 
through the refuse chute; Poon et al.'s (2001a) investigation of WGRs by checking truck load records is a similar approach.

\subsection{Main causes of wastes}

While investigating WGRs in the four projects, main causes contributing to the generation of waste are also analyzed as elaborated in detail below.

\section{Concrete}

Conventional cast in-situ reinforced concrete is the preferable technique for high-rise buildings in Shenzhen. Although concrete is the dominant construction material, mixing concrete on-site is banned owing to its noise and other environment problems. The concrete is premixed and transported to site through tilting drum trucks by sub-contractors using Just-in-Time (JIT) delivery and then pumped into formwork.

The research found that most concrete waste on the sites under study was caused by poorly constructed formwork. If the formwork was installed imprecisely or was broken, there would be some bulging or leakage, and leveling off and re-pouring would cause waste. A certain amount of concrete waste also occurred due to the use of prefabricated concrete piles for foundations. While piles are made in a standard length, the depth of foundation is often unknown. Piles are usually longer than needed and the part that remains above the ground level will be removed as waste. There was also some concrete waste from the spike hammer for facilitating the concrete pour for the 
next floor.

Our investigation also found that the waste of premixed concrete caused by excessive ordering is normally not an issue. But once it happens, it could significantly increase the WGR. For example, an exception occurred on Project A where approximately 326kg of premixed concrete was over-ordered and ended up as waste left on the site.

\section{Timber}

The main cause of timber waste on site is the formwork and falsework used for the placement of in-situ construction. Theoretically, a set of timber formwork can be reused for 8 to 12 times but according to the site managers on the projects under study, timber formwork can only be reused for 5 to 6 times and the old formwork left on the site as waste. The second reason for timber waste is cutting. Some cutting waste of broken margins will be generated after the removal of formwork. Finally, there may be some damaged formwork and falsework due to inappropriate storage such as being stacked on site without any protection. As shown in Table 2, timber waste outweighed any other waste including concrete in our investigated projects.

\section{Reinforcement}

All the projects investigated by this study used traditional steel reinforcement to improve the performance of the in-situ concrete. Operated by inexperienced mental cutters is the main cause of reinforcement waste. The use of prefabricated piles is 
another cause of reinforcement waste because when a pile protrudes above the required level and needs to be cut off, there will be reinforcement left on site as waste. In addition, steel reinforcement can rust easily if stored in a hypaethral shed without any weather proof covering and once it is seriously rusted, it cannot be used as reinforcement and therefore ends up as waste. However, on the four projects that were investigated the waste of metal, including reinforcement, was negligible. This was because metal is considered to be expensive and is relatively easy to sort and store on site. Even small off-cuts of reinforcement were picked up and stored properly on site for recycling; they were not counted as waste on any of the four projects.

\section{Bricks/blocks}

There are several causes of brick and block waste. The majority of the brick and block waste generated on the four projects investigated was from various cutting activities such as cutting due to the lack of a modular coordinated design and due to the installment of electrical boxes and pipe work for various services. A site manager suggested that cutting waste can attribute up to $10 \%$ of the bricks and blocks purchased. Poor unloading and storage is another major source of waste for brick and block. During the investigation, it was observed that the laborers who were responsible for unloading and storing the bricks and blocks usually piled them randomly, which resulted in unnecessary damage. Another cause of brick and block waste was re-working due to a design change. According to a site manager, design change does not happen frequently, but when it does occur it usually causes an 
enormous waste of bricks and blocks. This concurs with a study by Lu and Yuan (2010) conducted in Shenzhen, showing that fewer design changes is a critical success factor when managing construction waste.

\section{Mortar}

Generally, not much waste mortar is generated as a result of masonry work and plastering because the mortar dropped on the floor during these activities will be reused, although there will be more wasted mortar on construction sites where the on-site management is poor. It was observed that on all four of the projects investigated, the most waste was caused by carelessness during the horizontal and vertical transportation of mortar by wheelbarrow.

\section{PVC pipes}

The waste generated from the use of PVC pipes was not serious compared to other materials on the four projects investigated. The main cause of PVC pipe waste is the short and unusable lengths resulting from having to cut to size. Similar to reinforcement, PVC pipes are expensive and easy to sort on site for recycling. Nevertheless, some long pipes are discarded by laborers if the on-site management of that project is poor.

\subsection{Comparison of Chinese Norms on MLRs with the present WGRs}

The norms and specifications (N\&S) system in Chinese construction industry can be 
traced back to its central-planned economy before 1978. In this system, project price is calculated by incorporating quantities of work (e.g. labor, materials and plant) and unit prices, which are all specified in $N \& S$ ( $\mathrm{Lu}, 2006)$. Although the system is transforming to an international practice based upon bills of quantities (BoQ) and market price information, $N \& S$ still play an important role as guidelines in the industry. N\&S stations periodically publish the MLRs of all major materials used in projects, which is calculated as a ratio of the amount of loss to the total consumption of a specific material by weight ( $\mathrm{kg}$ or ton). In Table 3, a column was added to allow for a comparison between WGRs and MLRs in order to provide a better understanding of the waste generated by the construction process.

It can be seen from Table 3 that the WGRs derived from this research and the MLRs as shown in the $N \& S$ have different measuring units, which makes it difficult to compare. However, when contractors are preparing their bidding documents, they find that the MLRs given by the N\&S can be very useful because they indicate the tolerable rate of material loss and the amount that can be charged as a part of project price. Usually, using the MLRs in the N\&S as a guideline, a contractor will also produce internal MLRs to control its actual material use with the company. The margin between the MLRs in the N\&S and the internal MLRs can be perceived as a measure of the contractor's waste management abilities.

Although they both, to some degree, reflect the average level of waste generation in 
construction projects, the MLR and WGR serve different purposes in the Chinese construction industry. MLRs are based on historical statistics from past projects, although its emphasis is on future projects; they reflect what should be. On the other hand, WGRs are based on actual waste generation on site; they reflect what is. In addition, material loss as given in the N\&S is slightly different from material waste. Some material identified as a 'loss' can be reused on-site such as is the case with steel bar off-cuts. However, if the material has been recognized as waste, it means the material has already been through the recycle process and can be treated as having no residual value. Therefore, MLRs are not a replacement of WGRs, and vice versa.

\section{Recommendations}

Based on the above findings and discussions, it is able to make recommendations for improving C\&D waste management in Shenzhen. The WGRs indicate clearly that miscellaneous waste that cannot be further sorted accounts for a significant proportion in the whole waste generation which is evidenced by WGRs of project B, project C and project D. This demonstrates the importance of implementing waste sorting at source, which echoes with findings by Wang et al. (2010), showing that after taking on-site waste sorting practices, the overall proportion of wasted materials for reuse and recycling could increase from $14 \%$ to $24 \%$ by volume, and from $8 \%$ to $19 \%$ by weight. Therefore, the investigation of the WGRs led to a general principle- on-site waste sorting - that should be bore in mind in order to enhance C\&D waste management practice in Shenzhen. The experience grown up from Hong Kong, e.g. 
using a refuse chute for on-site sorting of C\&D waste (Poon et al., 2001b), can be a very useful reference for this practice in Shenzhen.

Specific measures for minimizing different wastes can also be recommended according to main causes of wastes identified above.

\section{Concrete:}

Interestingly, as identified above, the performance of formwork and falsework is a factor causing concrete waste. It is therefore recommended to improve the performance of formwork construction in order to reduce the most source of concrete waste. This aspiration has been captured by the increasing adoption of mental formwork and falsework in the industry. As will be elaborated later, the use of the mental formwork and falsework can also reduce the use of timber as another important source of waste. Attention should also be given to the length of foundation when prefabricated concrete piles are used; a careful design and a good communication with the foundation sub-contractor might be useful in this respect.

\section{Timber:}

The reduction of timber waste can be largely achieved through enhancing the management of formwork and falsework, such as increasing the times of reuse of formwork, reducing timber waste due to cutting, and taking proper measures to store and prevent formwork and falsework from being damaged. In view of the fact that 
conventional cast in-situ concrete technology is still dominant in China, replacing current timber formwork with metal formwork is yet to take place but it deserves serious consideration as one way of reducing timber waste. Module building will be an efficient way to reduce the waste generation from timber and other materials.

\section{Reinforcement:}

Measures for reducing reinforcement waste encompass employing skilful cutters, storing steel reinforcement properly to avoid being rusted. As reinforcement steel is supposed to be expensive and relatively easier for isolating vis-à-vis other wastes, onsite sorting for reinforcement is not really an issue.

\section{Bricks/blocks:}

Based on causes leading to bricks/blocks waste, contractors are suggested to reduce unnecessary brick/block cutting in construction and operate carefully when unloading and storing them. In addition, fewer design changes could also contribute to a lower WGR of bricks/blocks. It should be pointed out that in project B, project $\mathrm{C}$ and project D, bricks/blocks waste was mixed with other waste such as mortar. This implies that on-site sorting at source is also a potential measure to reduce the WGR of bricks/blocks.

Mortar and PVC pipes:

Results show that mortar and PVC pipes are wasted due to poor construction 
management. Specifically, waste generation of these materials are highly related to how to handle them by the workers. Therefore, enhancing the management and promoting workers' awareness of waste reduction is essential. Furthermore, establishment of an incentive reward program for encouraging workers to minimize avoidable material waste as suggested by Chen et al. (2002) might be a promising solution.

\section{Conclusions}

This research improves the understanding of $C \& D$ waste in the Chinese construction sector. The research revealed a C\&D WGR of $3.275-8.791 \mathrm{~kg} / \mathrm{m}^{2}$ in Shenzhen. WGRs for main materials including concrete, timber, metal, bricks and blocks, mortar, PVC pipes, and miscellaneous waste were investigated individually. It was found that miscellaneous waste, timber and concrete outweighed any other material as the main sources of C\&D waste in Shenzhen.

WGRs of main materials were also compared with MLRs as stated in China's N\&S and it was found that the WGR is not a replacement for the MLR, and vice versa. The WGR provides a better reflection of real waste generation on site. Finally, the construction industry in Shenzhen was suggested to reduce WGRs of different material wastes in a number of ways, typically including performing waste sorting at source, employing skilful workers, uploading and storing materials properly, promoting waste management capacity, replacing current timber formwork with metal 
formwork and launching an incentive reward program to encourage waste reduction.

Findings from the research will improve the creditability of statistics that are available for understanding C\&D WM in China, and the WGRs revealed will serve as valuable quantitative information for benchmarking different C\&D WM practices. Recommendations presented can be helpful for the construction industry when considering improving the performance of WM. Finally, the methodology used for the study will provide a useful reference for similar research in the future.

\section{Acknowledgements}

The authors would like to thank Professor Wang Jiayuan at Shenzhen University of China for the valuable support for the research. Special thanks are given to Miss Lin Zhenrong, Mr Wang Peiquan, Mr Zhang Yi and Miss Zhu Jiaolan for their work during the on-site experimental exercises. The two anonymous reviewers are highly appreciated for their constructive comments for making this paper more robust.

\section{References}

Bossink, B.A.G., Brouwers, H.J.H., 1996. Construction waste: Quantification and source evaluation. Journal of Construction Engineering and Management 122(1), 55-60.

Chen, Z., Li, H., Wong, T.C., 2002. An application of bar-code system for reducing construction wastes. Automation in Construction 11(5), 521-533. 
DETR (Department of the Environment, Transport and the Regions), 2000. Building a better quality of life - a strategy for more sustainable construction. DETR, London.

(EPD) (Environmental Protection Department), 1998. Monitoring of Solid Waste in Hong Kong. Environmental Protection Department, Hong Kong.

Formoso, T.C., Soibelman M.L., Cesare, C.D., Isatto, E.L., 2002. Material waste in building industry: main causes and prevention. Journal of Construction Engineering and Management 128(4), 316-325.

Forsthe, P., Marsden, P.K., 1999. Modeling construction waste performance - an arising procurement issue. In: Ogunlana, S.O. (Ed.), Profitable Partnering in Construction Procurement, CIB TG23 (Culture in Construction) Joint Symposium, Spon, London, 679-688.

Lampris, C., Lupo, R., Cheeseman, C.R., 2009. Geopolymerisation of silt generated from construction and demolition waste washing plants. Waste Management 29, 368-373.

Lin, Z.W., 2006. Model Development for Estimating the Quantity of A Single Building’s Demolition Waste. National Central University, 2006.

Lu, K.A., 1999. Status quo and comprehensive utilization of refuse produced from construction and removal of buildings in China. Construction Technology 28(5), 44-45.

Lu, W.S., 2006. A System for Assessing and Communicating Contractors' Competitiveness. PhD Thesis. Hong Kong Polytechnic University, Hong Kong. 
Lu, W.S., Yuan, H.P., 2010. Exploring Critical success factors for construction and demolition waste management in China. Resources, Conservation and Recycling 55(2), 201-208.

Mcdonald, B., Smithers, M., 1998. Implementing a waste management plan during the construction phase of a project: a case study. Construction Management and Economics 16, 71-78.

McGregor, M, Washburn, H., Palermini, D., 1993. Characterization of Construction Site Waste: Final Report. Presented to the METRO solid waste department, Portland, Oregon.

NBS, 2008. The Statistical Yearbook of China 2008. China Statistics Press: Beijing.

OCIO (Office of the Chief Information Officer) Enterprise Architecture Program, 2007. Treasury IT Performance Measures Guide. U.S. Department of the Treasury. May 2007.

Poon, C.S., 2007. Reducing construction waste. Waste Management 27, 1715-1716.

Poon, C.S., Yu, A.T.W., Wong, S.W., Cheung, E., 2004a. Management of construction waste in public housing projects in Hong Kong. Construction Management and Economics 22(7), 675-689.

Poon, C.S., Yu, A.T.W., Jaillon, L., 2004b. Reducing building waste at construction sites in Hong Kong. Construction Management and Economics 22(5), 461-470.

Poon, C.S., Yu, A.T.W., See, S.C., Cheung, E., 2004c. Minimizing demolition wastes in Hong Kong public housing projects. Construction Management and Economics 22(8), 799-805. 
Poon, C.S., Yu, T.W., Ng, L.H., 2001a, A Guide for Managing and Minimizing Building and Demolition Waste. Hong Kong Polytechnic University, Hong Kong.

Poon, C.S., Yu, T.W., Ng, L.H., 2001b, On-site sorting of construction and demolition waste in Hong Kong, Resources, Conservation and Recycling, 32, 157-172.

Reddrop, A., Ryan, C., 1997. Housing Construction Waste. Commonwealth Department of Industry, Science and Tourism, Canberra, 2.

Roche, T.D., Hegarty, S., 2006. Best practice guidelines on the preparation of waste management plans for construction and demolition projects. Available at: $<$ http://www.envirocentre.ie/includes/documents/BPGConstructionand\%20demo lition.pdf $>$.

Skoyles, E.R., 1976. Materials wastage - a misuse of resources. Building Research and Practice (July/August 1976), 232-243.

Tam, V.W.Y., Tam, C.M., Zeng, S.X., Ng, C.Y., 2007. Towards adoption of prefabrication in construction. Building and Environment 42(10), 3642-3654.

Treloar, G.J., Gupta, H., Love, P.E.D., Nguyen, B., 2003. An analysis of factors influencing waste minimization and use of recycled materials for the construction of residential buildings. Management of Environmental Quality: An International Journal 14(1), 134-145.

U.S. Environmental Protection Agency (EPA), 2002. WasteWise Update: Building For the Future. Available at: <http://www.epa.gov/wastewise/pubs/wwupda16.pdf>.

Wang, J.Y., Touran, A., Christoforou, C., Fadlalla, H., 2004. A systems analysis tool 
for construction and demolition wastes management. Waste Management 24, 989-997.

Wang, J.Y., Yuan, H.P., Kang, X.P., Lu, W.S., 2010. Critical success factors for on-site sorting of construction waste: a China study. Resources, Conservation and Recycling 54(11), 931-936. 


\section{Table 1 Previous studies of waste generation rates}

\begin{tabular}{|c|c|c|c|c|}
\hline Author & Country & Measurement of WGRs & Methodology & Conclusions \\
\hline $\begin{array}{l}\text { Skoyles } \\
(1976)\end{array}$ & UK & $\begin{array}{l}\text { Percentage by weight (of the } \\
\text { amount required according to } \\
\text { design) }\end{array}$ & $\begin{array}{l}\text { Direct } \\
\text { observation and } \\
\text { comparing } \\
\text { contractors' } \\
\text { records }\end{array}$ & $\begin{array}{l}2 \%-15 \% \text { by weight } \\
\text { according to the amount } \\
\text { purchased for } 37 \\
\text { materials }\end{array}$ \\
\hline $\begin{array}{l}\text { McGregor et } \\
\text { al. (1993) }\end{array}$ & USA & $\begin{array}{l}\text { Weight and percentage of total } \\
\text { waste from an individual project }\end{array}$ & $\begin{array}{l}\text { Questionnaire } \\
\text { and telephone } \\
\text { survey }\end{array}$ & $\begin{array}{l}\text { Varied with construction } \\
\text { type and project cost }\end{array}$ \\
\hline $\begin{array}{l}\text { Bossink and } \\
\text { Brouwers, } \\
\text { (1996) }\end{array}$ & Netherland & $\begin{array}{l}\text { Percentage by weight (of } \\
\text { purchased materials) }\end{array}$ & $\begin{array}{l}\text { Sorted and } \\
\text { weighed the } \\
\text { waste materials }\end{array}$ & $\begin{array}{l}1 \%-10 \% \text { by weight of the } \\
\text { amount purchased for } 7 \\
\text { materials, with an } \\
\text { average of } 9 \%\end{array}$ \\
\hline $\begin{array}{l}\text { Mcdonald } \\
\text { and Smithers } \\
\text { (1998) }\end{array}$ & Australia & $\begin{array}{l}\text { The volume }\left(\mathrm{m}^{3}\right) \text { of waste } \\
\text { generated per } \mathrm{m}^{2} \text { of gross floor } \\
\text { area }\end{array}$ & $\begin{array}{l}\text { Sort in waste bins } \\
\text { and delivery } \\
\text { records of bins }\end{array}$ & $\begin{array}{l}\text { Total waste rate: } 0.084 \\
\mathrm{~m}^{3} / \mathrm{m}^{2}\end{array}$ \\
\hline $\begin{array}{l}\text { Forsthe and } \\
\text { Marsden } \\
\text { (1999) }\end{array}$ & Australia & $\begin{array}{l}\text { Waste }=\text { ordered materials - in-situ } \\
\text { quantities }\end{array}$ & $\begin{array}{l}\text { In-situ quantities } \\
\text { were from } \\
\text { drawing or site } \\
\text { measurement; } \\
\text { ordered materials } \\
\text { were from } \\
\text { delivery and } \\
\text { order documents }\end{array}$ & $\begin{array}{l}\text { Maximal and minimal } \\
\text { generation rate for } 8 \\
\text { materials by percentage } \\
\text { in two projects }\end{array}$ \\
\hline $\begin{array}{l}\text { Poon et al., } \\
\text { (2001a) }\end{array}$ & Hong Kong & $\begin{array}{l}\text { Percent by weight or volume } \\
\text { according to different materials }\end{array}$ & $\begin{array}{l}\text { Site observation } \\
\text { and questionnaire }\end{array}$ & $\begin{array}{l}\text { 1-8\% for public housing; } \\
1-100 \% \text { for private } \\
\text { housing }\end{array}$ \\
\hline $\begin{array}{l}\text { Morris } \\
\text { Specifications } \\
\text { Inc. (2001) }\end{array}$ & Canada & NA & NA & $\begin{array}{l}\text { WGRs for main } \\
\text { construction materials } \\
\text { (wood, drywall, metal, } \\
\text { concrete, other) are given }\end{array}$ \\
\hline $\begin{array}{l}\text { Formoso et al. } \\
\text { (2002) }\end{array}$ & Brazil & $\begin{array}{l}\text { Waste }(\%) \\
{\left[\left(\mathrm{M}_{\text {purchased }}-\text { Inv }\right)-\mathrm{M}_{\text {designed }}\right] / \mathrm{M}_{\text {designed }}} \\
\text { Where Inv indicates the final } \\
\text { inventory of materials }\end{array}$ & $\begin{array}{l}\text { Direct } \\
\text { observation and } \\
\text { contractors' } \\
\text { records }\end{array}$ & $\begin{array}{l}19.1 \%-91.2 \% \text { by weight } \\
\text { according to the amount } \\
\text { purchased for } 8 \text { materials }\end{array}$ \\
\hline $\begin{array}{l}\text { Treloar et al. } \\
\text { (2003) }\end{array}$ & Australia & Not clear & $\begin{array}{l}\text { consultation with } \\
\text { construction } \\
\text { company } \\
\text { employees }\end{array}$ & $\begin{array}{l}3 \%-10 \% \text { for eight } \\
\text { materials }\end{array}$ \\
\hline Poon et al. & Hong Kong & The volume $\left(\mathrm{m}^{3}\right)$ of waste & visual inspection, & total \\
\hline
\end{tabular}




\begin{tabular}{|c|c|c|c|c|}
\hline (2004) & & $\begin{array}{l}\text { generated per } \mathrm{m}^{2} \text { of gross floor } \\
\text { area }\end{array}$ & $\begin{array}{l}\text { tape } \\
\text { measurement, } \\
\text { truck load } \\
\text { records }\end{array}$ & $\begin{array}{lr}\text { generation } & \text { rate: } \\
0.176 \mathrm{~m}^{3} / \mathrm{m}^{2}(\mathrm{C}) ; & 0.4-0.65 \\
\mathrm{~m}^{3} / \mathrm{m}^{2}(\mathrm{D}) & \end{array}$ \\
\hline Lin (2006) & Taiwan & $\begin{array}{l}\text { The volume }\left(\mathrm{m}^{3}\right) \text { of waste } \\
\text { generated per } \mathrm{m}^{2} \text { of gross floor } \\
\text { area }\end{array}$ & $\begin{array}{l}\text { the Neural } \\
\text { Network Method }\end{array}$ & $\begin{array}{l}0.85 \mathrm{~m}^{3} / \mathrm{m}^{2} \text { for factory } \\
\text { (D); } \\
0.54-0.66 \mathrm{~m}^{3} / \mathrm{m}^{2} \text { for } \\
\text { residential (D) }\end{array}$ \\
\hline $\begin{array}{l}\text { Tam et al. } \\
(2007)\end{array}$ & Hong Kong & $\begin{array}{l}\text { Wastage level }(\% \mathrm{~T})=(\mathrm{Mp} \\
-\mathrm{Mu}) / \mathrm{Mu} \times 100 \\
\text { where } \mathrm{Mp} \text { is the purchased } \\
\text { material and } \mathrm{Mu} \text { is the used } \\
\text { material (in } \mathrm{m}^{3} \text { for concrete, in } \\
\text { ton for reinforcement, in } \mathrm{m}^{2} \text { for } \\
\text { formwork, in } \mathrm{m}^{2} \text { for brick/block } \\
\text { and in } \mathrm{m}^{2} \text { for tile). }\end{array}$ & $\begin{array}{l}\text { Interview with } \\
\text { people involved } \\
\text { in the industry }\end{array}$ & $\begin{array}{l}8.9-20 \% \text { and } 4.11-6.62 \% \\
\text { by weight for } 5 \text { materials } \\
\text { according to different } \\
\text { sub-contracting } \\
\text { arrangements }\end{array}$ \\
\hline
\end{tabular}


Table 2 A summary of the profiles of projects under study

Project A: This project is a laboratory with a total construction area (TCA) of 46,999 $\mathrm{m}^{2}$, started from June 10, 2008, and was finished on Dec. 1, 2009. There are 9 floors up the ground and 1 under the ground with a height of $44 \mathrm{~m}$. The selected area was $399.834 \mathrm{~m}^{2}$ on the fourth floor.

Project B: This project is a cluster of residential buildings with a TCA of $14,5926 \mathrm{~m}^{2}$. There are 16 or 34 floors up the ground and 1 floor under the ground with a height ranging from $56.8 \mathrm{~m}$ to $103.7 \mathrm{~m}$. The selected area was $146.93 \mathrm{~m}^{2}$ on the $24^{\text {th }}$ floor, including 5 rooms and a walkway.

Project C-1: This project is a residential building with a construction area of $11,800 \mathrm{~m}^{2}$, started from Oct. 1, 2007, and was finished on Oct. 30, 2009. There are 29 floors up the ground and 1 floor under the ground with a height of 92.95m. The selected area was $135.25 \mathrm{~m}^{2}$ on the $18^{\text {th }}$ floor.

Project C-2: This is exactly same with the descriptions of Project C-1 except for the selected area being $135.25 \mathrm{~m}^{2}$ on the $15^{\text {th }}$ floor.

Project D: This project is a residential building with a construction area of 184,678m², started from Mar. 15, 2008, and was finished on Aug. 15, 2009. There are two blocks with 26 floors up ground and 1 under the ground with a height of 97.2m. The selected area was $78 \mathrm{~m}^{2}$ under the ground. 


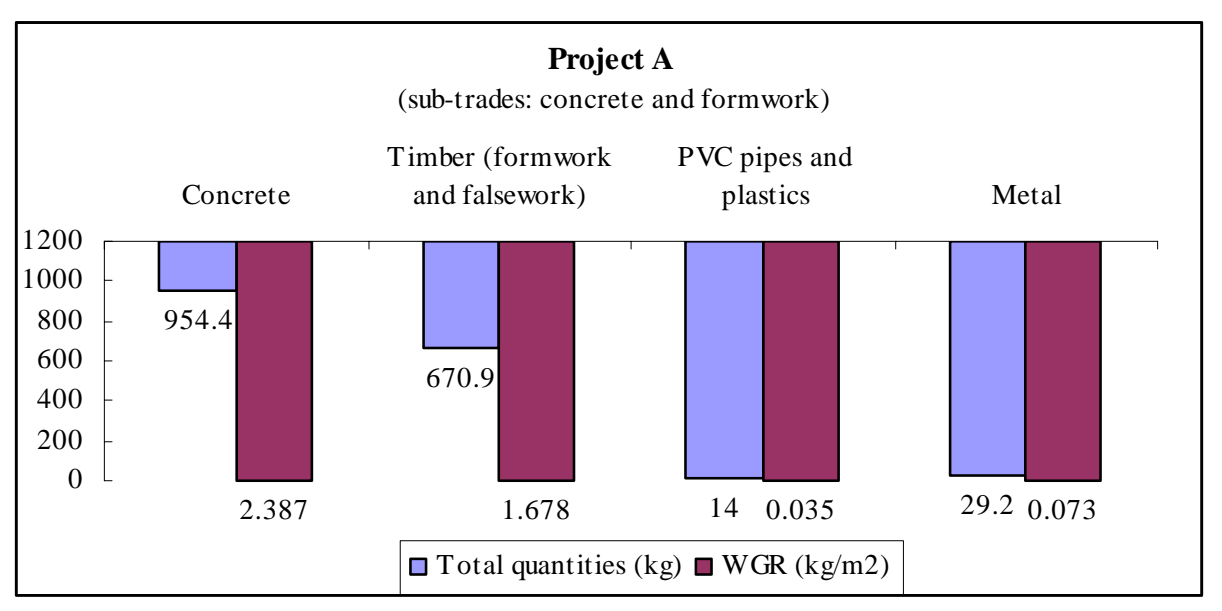

(a)

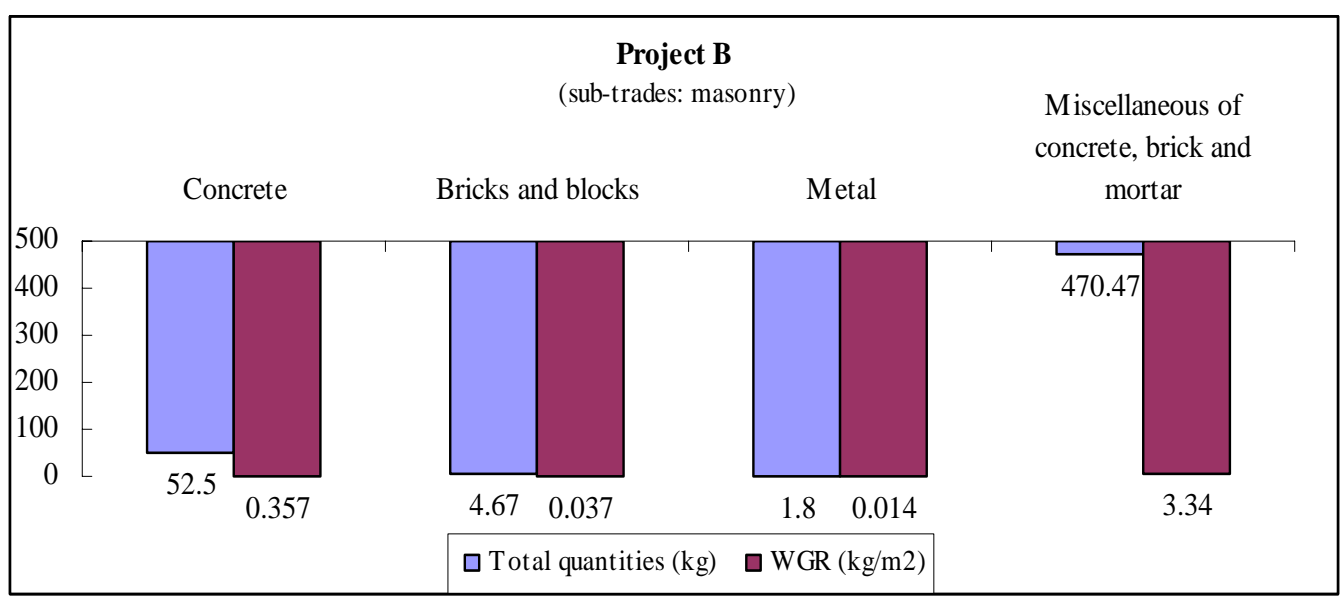

(b)

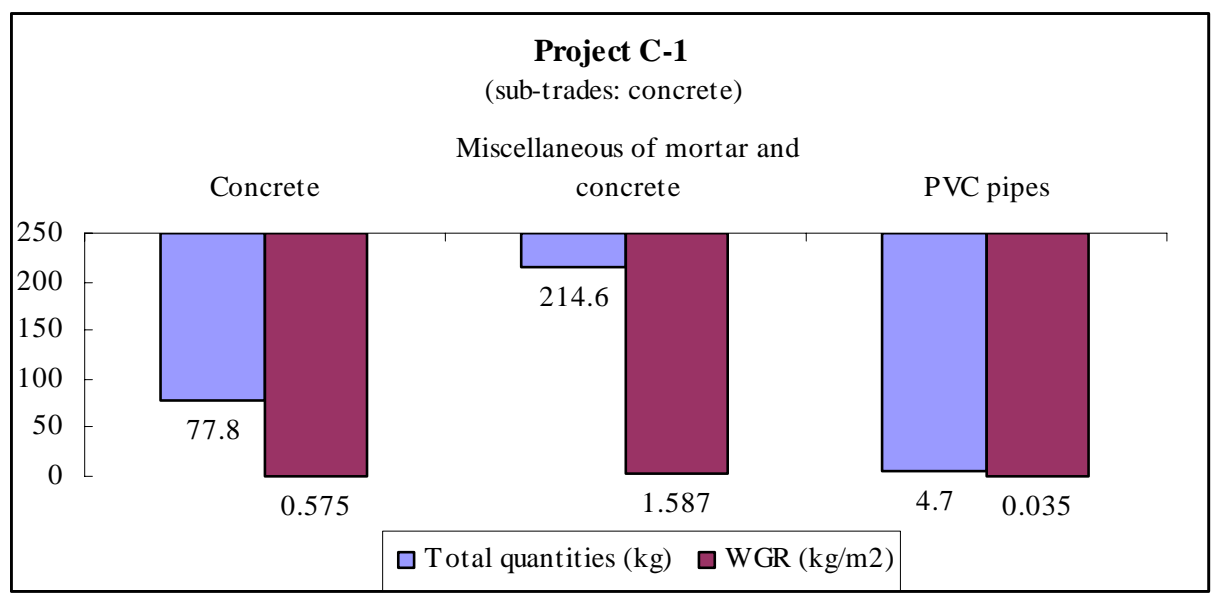

(c) 


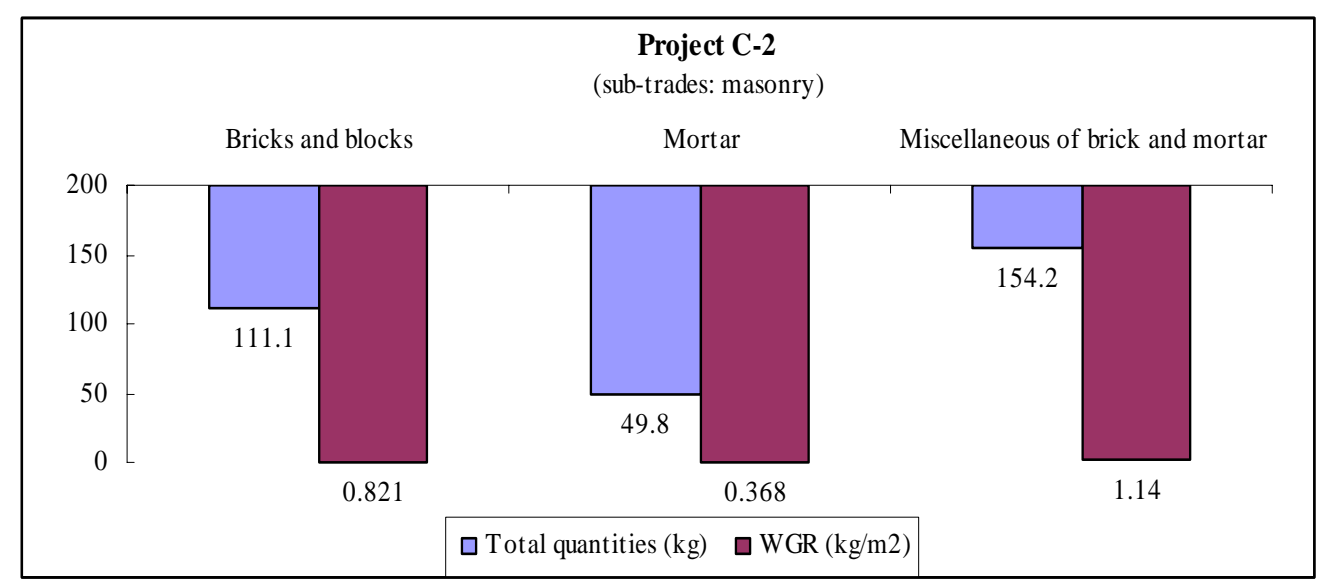

(d)

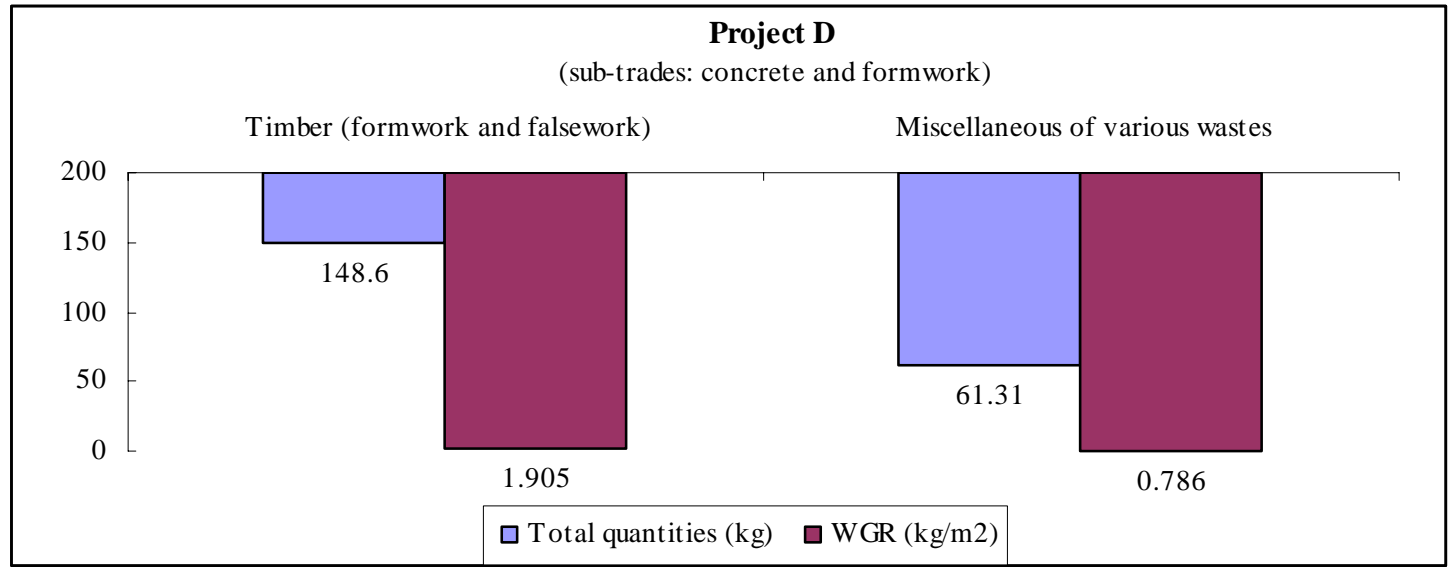

(e)

Figure 1 C\&D WGRs of the construction projects under investigation 
Table 3 Waste generation rates and material loss rates according to different

\section{materials}

\begin{tabular}{|c|c|c|c|}
\hline Materials & $\begin{array}{l}\text { Waste } \\
\text { Generation Rate } \\
\left(\mathrm{kg} / \mathrm{m}^{2}\right)\end{array}$ & $\begin{array}{l}\text { Mid-value of } \\
\text { WGR }\left(\mathrm{kg} / \mathrm{m}^{2}\right)\end{array}$ & $\begin{array}{l}\text { Material Loss Rate* } \\
\text { (Percentage } \\
\text { Purchased) }\end{array}$ \\
\hline Concrete & $0.357-2.387$ & 1.372 & 1.33 \\
\hline $\begin{array}{l}\text { Timber (from formwork and } \\
\text { falsework) }\end{array}$ & $1.678-1.905$ & 1.796 & 5 \\
\hline $\begin{array}{l}\text { Metal (including reinforcement } \\
\text { bar and fixing wire) }\end{array}$ & $0.014-0.073$ & 0.044 & 2.88 \\
\hline Bricks and blocks & $0.037-0.821$ & 0.429 & 7 \\
\hline Mortar & 0.368 & 0.368 & 3.95 \\
\hline PVC pipes & 0.035 & 0.035 & 1.05 \\
\hline Miscellaneous waste & $0.786-3.202$ & 1.994 & - \\
\hline Total & 3.275-8.791 & & - \\
\hline
\end{tabular}

* The column is adapted from the data in Shenzhen Construction Norms and Specifications (2003 version). 